\title{
Helga Druxes
}

German, Williams College

\section{Patricia Anne Simpson}

Modern Languages and Literatures, University of Nebraska

$\mathscr{H}$ istorian Geoff Eley argues that the idea of Europe has contracted from the ideal of a pluralistic community with the potential to integrate cultural "Others" to a "narrowly understood market-defined geopolitical drive for the purposes of competitive globalization." Global deregulation, he states, has produced streams of labor migrants and the tightening of Europe's external borders, while the economic expansion of Europe to more member countries since 1992 has opened up new divisions and inequalities among them. Aftereffects from the break-up of the East bloc can be felt in the escalation of antiminority violence in Central and Eastern Europe, as well as "the smouldering slow burn of the legacies of colonialism" in Western Europe. ${ }^{2}$ These diverse pressures and anxieties coalesce on the spectral figure of the Islamic fundamentalist at Europe's gates.

Right populist groups profit from these anxieties by averring that the problem lies not with their own racism, which they strategically disavow, but rather with the caveat of a profound cultural incompatibility of Islam and democracy. They claim that this difference is observable through the ages and therefore immutable, that its invasive potential must be countered by an assertive identitarian nationalism from within "Fortress Europe." In his analysis of far right politics in Austria, political scientist Farid Hafez draws attention to the dominant strategy of anti-Islamic populism: "This is based on a monolithic, not differentiated and homogenous perceived Islam, which is used for construing boundaries and antagonistic confrontation. Islam is seen as inferior, but also as hostile, aggressive and threatening." ${ }^{3}$ By falsely positing that Muslims hew to a monolithic Islamic identitarianism, European right-wing populists validate their own aggressive assertion of nativist and racist agendas. 
Against this political and social landscape, the agents of extremism and proponents of populism reduce the multitude of tensions and stressors of life under globalized neoliberalism simplistically-but comfortingly-to a concrete enemy. This enemy needs to be excluded, even killed, because any less would constitute a betrayal of the white race and proprietary beliefs in a national homeland-so nativist advocates of autarky and Islamophobic xenophobes avow. From the lone-wolf terror attacks perpetrated by Anders Behring Breivik against Socialist party youth that stood for multicultural integration in Norway, to the ten-year spree of National Socialist Underground (NSU) murders of mostly Turkish German small business owners, to the knife attack on Cologne mayor Henriette Reker, to the June 2016 shooting of British Labour MP Jo Cox by white supremacist Thomas Mairthese and other acts of violence are supported by a globalized vengeful chauvinism that is not ashamed to revive fascist and colonial-era stereotypes about racial and genetic inferiority and non-belonging.

Sociologists Richard Alba and Nancy Foner note that "in much of Western Europe, religion has come to be viewed as a problem for immigrant minorities and for the societies in which they now live. The concerns and tensions [since the 1990s] are almost exclusively about Islam ... a prevalent view is that the culture of Islam and that of the West are irreconcilable." ${ }^{4}$ In 2010, controversy swirled around a bestseller by German banker and politician Thilo Sarrazin. His Deutschland schafft sich ab (Germany Abolishes Itself) foregrounded anxieties about Muslim and Arab immigrants as unassimilable cultural aliens in Germany's changing demographics. The 2015 Islamist murders of staff at the Paris satirical magazine Charlie Hebdo led to huge protest marches in France and Germany, among other Western European countries, on behalf of free speech. Increasingly strident debates on the supposedly illiberal tendencies of a monolithic Islam have become mixed up with fear of terror attacks by radical fundamentalists, as well as with anxieties about globalization. Nowhere is this toxic brew more evident than in the sudden rise of Patriotic Europeans Against the Islamization of the West or Occident, more commonly known as Pegida, a xenophobic German populist movement that cultivates transnational links.

While the numbers at its raucous Monday marches fluctuate, Pegida capitalizes on Euroskeptic nativist tendencies and Islamophobia. Its supporters can be found in various East and West German cities and increasingly also transnationally, in the UK, Estonia, Spain, Hungary, Russia, and the United States. ${ }^{5}$ Pegida also foments a virulent anti-intellectualism that targets journalists and career politicians, whom they deride as members of corrupt elites. This populist movement represents a recent generation of extremism 
that exerts constant pressure on centrist parties and politics while refraining from positive political engagement. In his work on the media and the far right in Western Europe, Antonis A. Ellinas follows the historical trajectory of right-wing political parties through the postwar decades in the Federal Republic, from the three parties of the far right (German Rightist Party, German Empire Party, and the German Community) founded in the late 1940s, to the establishing of the National Democratic Party (NPD) in 1964, to the subsequent emergence of the Republikaner in the 1980s. ${ }^{6}$ Ellinas identifies a general, Western European shift from materialist-oriented political issues toward national identity as an embattled category and as the primary territory of the far right. He writes:

The political turn toward national identity has taken different forms in different countries in different times but has caused similar political rifts between those who defend or oppose certain conceptions of the national collective. ${ }^{7}$

Writing in 2010, Ellinas further characterized Germany as a country in which the far right did not experience the electoral success that would lead to representation at the national level. From the political margins, Pegida plays the nationalist card while repudiating any extremism.

Refusing to fit into the traditional party system, Pegida's proponents have become a venue for a disgruntled "antipolitical" sentiment against parliamentary democracy, even as their leaders attempt to build strategic links to the far-right populist party, the Alternative für Deutschland (Alternative for Germany, AfD) and other political organizations of the New Right. After its initial success in fall 2014, Pegida was subsequently beset by leadership struggles, leading to the resignation of its founder Lutz Bachmann, a known career-criminal who also posed on Facebook with a Hitler hairstyle and moustache. The moderates left the group, and by early summer 2015, attendance at the weekly protest marches had dwindled to just a few hundred.

It now appeared that Pegida's agenda and membership had been absorbed by the AfD, which had in the meantime also undergone a schism and shifted dramatically to the right under the new leadership of Frauke Petry and Björn Höcke. Nonetheless, the refugee crisis that unfolded in July and August of 2015 provided new fuel for Pegida's street protests. A further boost to Pegida's fortunes came in the form of the January 2016 sex attacks in Cologne and other German cities. The Pegida protests swelled again to previous highs of 6,000 to 10,000. In March 2016, the AfD gained dramatically in three regional elections and adopted a more strident tone on border securitization, advocating closing Germany's eastern borders and shooting at refugee women and children. While these statements proved too incendiary and had 
to be partially retracted by Petry, they did get a lot of exposure in the media, often in the form of sensational talk shows rather than reasoned debate.

The success of populist, nativist far-right parties and identitarian movements that increasingly situate themselves in the political mainstream, exacerbates an ongoing struggle to preserve the reality, if not the ideals, of the European Union (EU), now more centrally in the crosshairs of far-right rhetoric and politics since the Brexit vote in June 2016. The EU enforces harsh austerity programs on its debtor members, securitizes its external borders with increasingly ramped-up militarization, and increasingly warehouses asylum seekers in neighboring countries rather than admit them to the benefits of the welfare state. Race relations scholar Liz Fekete points out how these authoritarian practices create convergence between the EU as an organization and the nativism of far-right groups, which also espouse protectionism, albeit on the much smaller geographic scale of a nation state. ${ }^{8}$ With the singular exception of German Chancellor Angela Merkel's fall 2015 invitation to Syrian refugees to seek safe haven in the EU, the European Union is a common market that seeks to assert itself in a globalized, neoliberal marketplace and no longer champions humanitarian principles regarding the right to asylum and other basic human rights for refugees, as established in the Geneva Convention.

Aftereffects of the global financial crisis of 2008 still reverberate in the struggling economies of many EU member states, lessening solidarity among them and fuelling opposition to transnational trade agreements with traditional partners like the United States. Even though the German economy remains the strongest within the EU, fears of another downturn and a sense of looming instability make many Germans vulnerable to xenophobic demagogues. Studies show that these anxieties affect not only the underclass and working-class Germans, but also the affluent middle and upper-middle classes. The neoliberal marketplace with its mantra of efficiency and leanness provoked critical reactions to the governments attempting to implement it. Nevertheless, neoliberal ideology per se also dovetails neatly with nativist panic-mongering about strained resources and flooding by culturally remote strangers. On the one hand, populists blame the state for cronyism and mismanagement; on the other hand, their own economic agenda relies principally on nativism and restricting access to welfare. Populists thus find themselves unwittingly allied with the austerity-driven tenets of neoliberalism within the Eurozone, which also enforces restrictive hiring policies and ties the right to social services to workfare. We may thus conceptualize Pegida as part of a neoliberal belief set, with the group's principal distinction being that it calls for violence against cultural others and political opponents more openly. 
Moreover, there are ideological overlaps in the Euroskeptic and antifederal views disseminated by groups like Pegida and mainstream conservative parties. In February 2016, Bavarian president Edmund Stoiber and the chairman of the CSU Horst Seehofer did an end-run around Merkel and the federal government, by traveling to Russia to meet with Vladimir Putin. They were looking for new transnational alliances, like many in the transnational far right. Eastern Pegida supporters carried placards at demonstrations in Dresden, with the imploring imperative: "Putin help us!" In another example, the AfD translated its party platform into Russian to appeal to the large number of Russian Germans residing in Brandenburg, a region known for its close economic ties between mid-sized companies and the Russian Federation. ${ }^{9}$ Right-wing populism generally holds Russia up as a model against local democratic elites. Just as Seehofer and Stoiber voiced their discontent with their party leadership in Berlin, populists stoke hatred of traditional political elites, descrying them as corrupt and remote from the concerns of ordinary people. The self-dramatizing character of their outrage strives for greater legitimacy, by seeking out the backing of similar movements and groups both within Germany and transnationally. Fekete draws attention to the fact that while far-right movements champion autarky and national economic protectionism, "European extremists also work behind the scenes to form an alternative transnational pole to globalization, a new international brotherhood of nation-states." 10

In many ways, Pegida espouses disgruntled nativism and local entitlements while demonizing the forces of globalization that threaten the German-ness of the nation-state. The Federal Republic of Germany finds itself at the epicenter of the European refugee crisis, alone among EU states attempting to accommodate and absorb more than one million refugees, asylum seekers, and other migrants. The polarized response to Merkel's decisions range from accolades for a commitment to open borders, human rights, and a nearly redemptive belief in a Germany without walls; to gender-based ridicule and calls for her arrest. The hospitable image conveyed by the Willkommenskultur or "culture of welcoming" has evolved from an erstwhile marketing strategy of the tourist industry to a contemporary response to far-right and nativist demands to close the borders. The Willkommenskultur includes a wide range of organizations, services, and even apps to assist recently arrived refugees; it has garnered accolades for Germany from the international community. The chancellor presides over the territory of cosmopolitanism and openness. Time magazine chose Merkel as Person of the Year (2015), not only for her handling the European economic, but also the refugee crisis: 
Merkel's legacy-her bold, fraught, immensely empathetic act of leadership-challenges more than the comfort of European life. It also challenges the comfort of assumptions about any group, including, if it works out, Germans. ${ }^{11}$

On the opposite side of the political spectrum, self-validating publicists, activists, and politicians lambaste the chancellor with headlines descrying her as "Queen of the smugglers" (Schlepperkönigin), "multi-culti mommy" (Mutti-Multikulti), or issuing the command "arrest Merkel." 12 The disparaging tone of the discourse heightens the conflict between local detractors who feel betrayed by neoliberalism and the cosmopolitics implicit in the German Willkommenskultur.

With the rise of Pegida and its multiple affiliates, from Leipzig's influential Legida to Mvgida (Mecklenburg-West Pomerania), the single-issue platform against Islam has mainstreamed Islamophobia, tapping into the vein of fear and resentment of homogenized Muslim identities; the tone has become ever more strident. Despite the fact that the turnout at various -gida meetings has tended to be low, the frequency of public demonstrations on the right spectrum in multiple locations ultimately generated stronger support for the right-extremist fringe, organized around the issues of refugees, migration, immigration, and asylum. This momentum enables splitter movements to agitate on small scales, which the journalist and right-extremist expert Olaf Sundermeyer defines as a "hyperactive scene" that empowers "a strong self-legitimation of the far right." ${ }^{13}$ While Pegida has neither a political platform nor the force of a social movement, its unwavering focus on the purported Islamization of Europe encompasses a spectrum of issues that function as tributaries into mainstream populist politics. In their introduction to From the Far Right to the Mainstream, Humayan Ansari and Farid Hafez examine expressions of anti-Muslim sentiment from all over Europe, citing evidence related, among other topics, to campaigns opposed to the building of mosques and minarets (depicted in one campaign as missiles) from Switzerland, Germany, Denmark, and the UK. They identify the relationship between the increase in Islamophobia and the rise and success of far-right and populist parties in the first decade of the twenty-first century. The authors point out that emphasizing the threat of Islam helped win over voters who would not consider themselves to be racist: "By targeting Islam, [populist-nationalist groups] were also able to tap into wider worries over the slow demise of old national identities in the face of increasing multiculturalism and globalization." ${ }^{14}$ The reciprocal relationships between singleissue protest phenomena, such as Pegida, and emerging parties with political momentum, such as AfD, overlap in Venn-diagram fashion with 
regard to immigration. Polling data reveal that AfD voters, for example, express concerns about immigration, social security, and a stable currency, but according to political scientist Frank Decker, "AfD voters were more than three times as likely to mention immigration as a decisive topic." 15 Pegida, though its numbers ebb and flow, remains poised to mobilize when necessary, an aggregator to channel populist frustration with the status quo into a political voice. ${ }^{16}$ The interactions and overlaps between groups like Pegida and the emerging political parties demonstrate the fluidity between transnational impulses and translocal articulations of populist agendas.

The rhetoric mobilized by populist and nationalist groups has only become more inflammatory in response to the presence of refugees, especially in the Federal Republic of Germany, the majority of whom are Muslim. Ansari and Hafez define and problematize the term Islamophobia in the context of the 1997 Runnymede Trust's report, which focused on Great Britain, and further explore connections to racism, antisemitism, and the pressure exerted by xenophobic and Islamophobic parties across the European political landscape. Pediga effectively instrumentalizes Islamophobia to exert such influence while maintaining contempt for political argument in the public sphere. In this way, Pegida speaks from the position of a Freudian id, articulating the unspeakable and flaunting taboos while blaming their marginalization on the rise of censorship in the form of political correctness. Ansari and Hafez diagnosed the symptoms of this condition in their earlier reading of European political tensions:

The failure of mainstream European politicians to effectively challenge the nativist arguments of far-right groups, together with the former's opportunistic attempts to win back votes by mimicking the latter's rhetoric and by pandering to the same fears that made right-wing groups popular, resulted in a wider population being attracted to farright messages. ${ }^{17}$

As a result, the political center cannot hold-as demonstrated in the fraught election process between a candidate from the Freedom Party of Austria (FPÖ) and a Green Party candidate in the 2016 Austrian presidential election and its aftermath.

In the Federal Republic, Pegida has expanded beyond mainstreamed Islamophobia to proclaim an antigovernmental, essentially nativist commitment to a status quo that excludes otherness. The adherents lament the loss of their way of life, which they partially attribute to the tide of refugees engulfing the Federal Republic today. ${ }^{18}$ With successful outreach to organizations throughout Germany and beyond its borders, the anti-immigration stance has grown to occupy common ground with radical populist parties, 
neo-Nazi Kameradschaften, media moguls, and self-appointed experts on identitarian truths and nativist entitlements. These groups also reinvigorate the historical rhetoric of National Socialism in the supposed service of "diversity;" they espouse traditional gender roles and host conferences about the family; they excoriate the EU and demand Merkel's resignation and imprisonment without offering any reasonable political alternatives. ${ }^{19}$

Linguist Ruth Wodak scrutinizes rhetorical strategies of European populists in countries ranging from Austria and Switzerland to France, the Netherlands, Poland, Hungary, and beyond. She draws attention to their frequent use of scapegoating: "sometimes the Bad Apple frame is used by referring to an alleged villain within the opposition or in a stigmatized minority group; or a conspiracy is constructed as cause by a strategically 'useful' scapegoat." ${ }^{20}$ Constructing Merkel as the scapegoat for the European refugee crisis thus facilitates several key populist goals at once: first, deflecting from the crisis' true causes; second, reactivating sexist clichés by casting Merkel as a naïve "mother of the nation" who "invites too many" to her home. ${ }^{21}$

The next level of interpreting this discourse implies that traditional gender norms need to be reinvigorated. "Gender mainstreaming," by extension, has gone too far. The semantics of these accusations appeal to an irrational argument: "We" the people ought to discipline such a silly woman by: a) making her apologize; and (b) replacing her altogether with a "sovereign" nation acting on its own. The presumptive "people" would decideprompted to take such drastic measures by external forces-to close Germany's external borders, reactivate the suspended Dublin accords, and send an unequivocal message to global refugees (now relabeled "migrants"-thus eliding humanitarian principles of caring for international refugees set forth in the Geneva Convention and German Basic Law) to stay wherever they are outside Europe, or at its external periphery.

The rhetorical strategies consistently implemented reveal a demonization of a female leader and a collapse of victims into a category of unwelcome invaders. Through a semantic post hoc fallacy, ${ }^{22}$ Merkel becomes conflated with the "bad" Others at Germany's door. Populists inside Pegida and AfD demand her removal by plebiscite-the oft-repeated Pegida mantra "Merkel muß weg" 23 (Merkel must go) might imply more drastic ways of doing away with her-since "German citizens were never consulted whether they want to cope with it (es schaffen)." ${ }^{24}$ Such mediatized scapegoating strategies disseminated via talk shows, on Facebook, and by street mobs attempt to short-circuit democratic processes of contestation within a parliamentary system. It is democracy itself that these demagogues "want gone," supplant- 
ing it with a fascistic brew of gendered intimidation mixed with calls for racialized violence. The rhetorical strategy associated with populists' excitable speech patterns and substance-less argument that defies any empirical fact-checking but nonetheless resonates with supporters has a new label, "Themenhopping." 25

There is evidence of at least some cause-effect relationship between strident speech and violent action, though proving such connections can be challenging and controversial: the line between hate speech and merely uninhibited speech can be blurred. Far right attempts to physically intimidate reach beyond the press and political opponents, as the following examples illustrate. Pegida's violent actionistic rhetoric appears to legitimate actual street violence, as in the case of Ine Dippmann, an MDR (Central Germany Television) journalist who was beaten at the 11 January 2016 Legida rally that she attended in order to report on the event. A few moments before, keynote speaker Tatjana Festerling had railed against "those elites that betray the people and fill them with hate, [citizens, seize pitchforks and] drub them out of the parliaments, the law-courts, the churches and the newspaper offices." ${ }^{26}$ Festerling subsequently faced a hate speech charge brought by the DJV (German Association of Journalists). After the rally ended that night, around 250 Neo Nazis and Hooligans attacked people, trashing homes and businesses in Connewitz, a Leipzig suburb where leftists are known to live. By the morning of 12 January, local police logs documented 226 arrests of violent Neo Nazis and Hooligans. ${ }^{27}$ Unknown assailants, using homemade acid bombs, attacked the family of Saxony's Justice Minister Sebastian Gemkow while they were asleep in their home. German historian Ralf Melzer, in an interview with the Federal Justice Minister Heiko Maas, touched on the topic of hate speech and criminality, and recent reforms in the justice system are increasing accountability for hate crimes. In the legal code, Paragraph 46 was reformed to include the racist, xenophobic, and generally dehumanizing motivations of criminal activities in the sentencing of convicted criminals. ${ }^{28}$

A heightened awareness of hate crimes does not prevent the harboring of resentment toward refugees and migrants, driven by a panic about diminishing social resources. This panic, however, deflects from the real cause of these cutbacks, for which the neoliberal policies at the federal level are to blame. The "crisis" ultimately devolves onto the larger stability of the European Union and its identity. The othering of migrants driven by "fear, racism and paranoia" 29 threatens to "derail the entire European project," 30 but also ignores the economic contributions migrants will make to receiving countries with an aging workforce. Frank-Jürgen Weise, the new Chief 
of the Federal Employment Agency, welcomes migrants. By October 2015 he anticipated that of 800,000 refugees, roughly 40 percent would stay in Germany and of this group, 70 percent are of working age; he refers to them in relatively positive terms: "a useful addition (gute Bereicherung) to our society and our labor market." ${ }^{31}$ In the larger context of immigration and integration issues, educational levels are significant. Data from 2007-2008 indicate that the highest educational level attained among second-generation Turkish Germans was a dispiriting two-thirds lower than those of Germans eighteen to thirty-five years old-these numbers may differ in the future for Syrian refugees, a third of whom have higher educational attainment on arrival. ${ }^{32}$ Initially, however, the German government as well as potential employers will have to invest significant resources into the refugees' administrative processing, education, and job training, beginning with intensive language courses-currently, these only become available to asylum applicants after a three-month waiting period. The language gap and the enforced indolence of most new arrivals may aggravate cultural tensions between nativists and refugees.

The xenophobic public climate, however, emboldens some to express unwarranted rage towards foreigners. Two scandalous cases reported in June 2016 stand out: a prestigious Kenyan writer on a stint as a German Academic Exchange Service visitor in Berlin and an Iraqi refugee in Arnsdorf, Saxony, were trying to transact simple everyday purchases and were severely beaten. Binyavanga Wainaina, who suffers from the aftereffects of a stroke, was thrown out of a cab and beaten by the driver because he was taking "too long" to search his phone for the destination address. ${ }^{33}$ The Iraqi man, who had been diagnosed as undergoing psychic trauma, was beaten by four local men, including a local CDU party rep, and chained to a tree before the police intervened. ${ }^{34}$ The attacks on refugee shelters in Germany also increased fivefold to more than 1,000 in 2015 compared to 2014..$^{35}$ These numbers are rising dramatically.

\section{The Contributions}

This special issue analyzes Pegida and its supporters in the context of their media presence, pressure on the far right and populist and mainstream politics, the gendered and racist discourses that accompany the Islamophobic platform, and the general ability to destabilize not only European identities but also, through the mobilization of populist politics, perhaps even the European Union. More generally, the following articles examine the inter- 
sections between Pegida's politics and antidemocratic, antipolitical, and antiglobalization anxieties. Helga Druxes' article isolates the central issues of the controversy about Pegida, documenting the struggles over its image and leadership strategies, and she exposes the group's extremist foundations of xenophobic, misogynist, and racist ideology, which run against selfproclaimed tolerance and commitment to moderation. Furthermore, her attention to gender performativity as it interacts with a revitalized image of a singular German phenotype reveals the unarticulated alignment between fascist ideology and contemporary pan-Aryanism.

Patricia Anne Simpson examines the intricately and translocally woven connections among representative movements, organizations, and media personalities who, while popularizing New Right and Euroskeptic views and disseminating them widely through social media and their own Internet websites, officially repudiate any extremism. Their ideologies overlap significantly and sometimes overtly with Pegida's platform. With their diatribes about the mainstream press, the failure of democratic politics, and the aggregate loss of national German identity and the putatively antidemocratic politics of Chancellor Angela Merkel, the cadre of self-credentializing ${ }^{36}$ "publicists" and politicians mobilize historical moments and contexts with the goal of crafting alliances with a broad spectrum of supporters.

David N. Coury focuses on the cultural opposition so stridently mobilized by the far right. Using Samuel P. Huntington's seminal essay "The Clash of Civilizations?" (1993) as a point of departure, Coury brings to bear Huntington's prediction of a coming civilizational conflict between the West and the Islamic World upon the current refugee crisis in Europe. ${ }^{37} \mathrm{He}$ explores the ways that Pegida has appropriated this cause, opposing not only the settling of refugees but also any construction of a multicultural state. They insist on the fundamental opposition between the Islamic Orient and imagined national communities, constructed as a "Fortress Europe" and serving as a bulwark of European cultures in an agonistic struggle.

In her article, Beverly Weber analyzes the specifically racialized and sexualized images that circulated in response to the New Year's Eve violence as it was represented in print and social media. This examination deepens an understanding of not only German semiotics of otherness, but also the attempt by organizations such as Pegida to reassert an essential European identity in response to a perceived threat. Weber raises a series of challenging questions that are uncomfortably centered on the disjunction between Europeanized ideals of human rights discourses on the one hand, and the conceptualization of violence that does not replicate binary models of the European self and the racialized other. In response, she looks instead at 
alliances that resist this either/or, including a hashtag campaign entitled \#ausnahmslos. Weber's analysis demonstrates that such emerging alliances can offer an alternative model that reimagines the human as a category untethered from Europeanness. By disavowing racism and defending nativist entitlements, Pegida's proponents effectively reassert whiteness as the essential credential for citizenship-national, global, human.

In the media coverage of Pegida's influence, refugee "crises," and political attacks on Merkel's government, little international attention has been paid to the responses within the Federal Republic from established Islamic organizations and communities. Karolin Machtans focuses on precisely the voices that have intervened in a public debate, which has tended toward a representation of Islam as an undifferentiated monolith. In her article, she compares the public responses of the Central Council of Muslims in Germany (ZMD), the Turkish-Islamic Union for Religious Affairs (DITIB), and the Islamic Council of Germany (IR) with those of the Liberal Islamic Federation (LIB), demonstrating how the perception of the homogenization of these diverse organizations can lead to significant conflicts of interest. Machtans analyzes various articulations of Islamophobia in the Federal Republic, with particular attention to its discernible rise among the German middle classes. The pressure to respond to Islamism is shared among Germany's Muslim organizations, yet they find themselves facing a dilemma: by speaking with one voice against extremism to non-Muslims, they may seem to reinforce the rhetorical and political essentialization of a singular and homogeneous Muslim community.

In his contribution to this special issue, Farid Hafez cogently analyzes the failure of Pegida (Austria) as a social movement through an examination of its poor performance through three theoretical lenses: political opportunity structures, ideology, and resource mobilization. His careful assessment of Pegida encompasses the Austrian political landscape in general, with special attention to the established anti-immigration and Islamophobic platform of the Freedom Party of Austria (FPÖ). Beyond the scope and depth of his arguments about the role of the far right in the Austrian national imaginary, Hafez' approach additionally demonstrates the importance of cross-referencing national organizations of particular transnational and translocal social movements, such as anti-Islamization groups, in order to understand the historical dynamic that factors into the larger political equation. 


\section{Conclusion}

The reactionary public climate engendered by extremist politics in the EU, finding venues of expression in the street, print, social media and in the polls continues to impinge on domestic national agendas, particularly but not exclusively in the Federal Republic. With issues as fundamental as human rights, open borders, national security-and the stamina of German democracy at stake-the confrontational modus operandi of right-wing populist publicists and politicians (immune to a frequently more moderate opposition), deteriorates into irrational and inflammatory rhetoric that may destabilize larger-political cultures and their constituencies. The gendered, racialized, and sexualized representations that dominate public dialogue about refugees, migrants, and nativist identities seem to preclude rational argument, deflating optimistic and pragmatic pronouncements, such as "We can do this." One thing emerges with painful clarity: the Federal Republic has become the focal point of a global and geopolitical fact. With an estimated 12 million stateless and 65 million displaced persons worldwide, it is imperative to turn down the volume of the shouting match between extremist positions and seek postnational solutions.

It has become equally clear that the construct of a Heimat still lures the political imaginary of the European far right. As Wodak writes,

... such nostalgic imaginaries are combined with and reinforced through anger and fear: anger about the alleged loss and fear of alleged new threats. These in turn lead to opposition against any transnational and globalized policies, against the EU specifically-which is perceived as initiating undesirable changes, and against cosmopolitanism more generally. ${ }^{38}$

Pegida and AfD seek to combine a reactionary nativist discourse with a new level of transnational potency within an international brotherhood of rightwing movements on the global stage. These alliances seek out geopolitical realignments that would transcend Europe and its traditional reliance on western allies like the United States by cultivating relations with expansionist authoritarian regimes such as Putin's Russia. Globalization has spawned a critique on the far right, even as it copies the very mechanisms of such extremism, using transnational crises as catalysts for the project of racialized nation-building.

Helga Druxes is Professor of German at Williams College. Recent publications include the co-edited volumes Digital Media Strategies of the Far Right Across Europe and North America (Lanham, 2015) and Navid Kermani (Bern, 
2016) and articles on female labor migration in documentary film, and literary critiques of neoliberalism.

Patricia Anne Simpson is Chair of the Department of Modern Languages and Literatures at the University of Nebraska in Lincoln, where she is also Professor of German. Her monograph, Reimagining the European Family: Cultures of Immigration (New York, 2013), examines the effects of recent patterns of immigration on the representation of the family in Europe. Author of Cultures of Violence in the New German Street (Lanham, 2012) and The Erotics of War in German Romanticism (Lewisburg, 2006), Simpson has also co-edited several volumes on literature, religion, and visual cultures in the Age of Goethe. With Helga Druxes, she co-edited the interdisciplinary volume Digital Media Strategies of the Far Right in Europe and the United States (Lanham, 2015). The recipient of numerous grants as well as research and teaching awards, Simpson is currently completing a book-length study about the play world and childhood in transatlantic modernity.

\section{Notes}

1. Geoff Eley, "Fascism Then and Now" in The Politics of the Right, ed. Leo Panitch and Greg Albo (London, 2015), 91-117, here 109.

2. Ibid.

3. Farid Hafez, "Jörg Haider and Islamophobia," in From the Far Right to the Mainstream: Islamophobia in Party Politics and the Media, ed. Humayan Ansari and Farid Hafez (Frankfurt/Main, 2012), 45-68, here 49.

4. Richard Alba and Nancy Foner, Strangers No More: Immigration and the Challenges in North America and Western Europe (Princeton, 2015), 119.

5. For a comprehensive overview of right populist groups in Europe, see Walter Baier, "Europe at the Crossroads" in Panitch and Albo (see note 1), 68-90.

6. Antonis A. Ellinas, The Media and the Far Right in Western Europe: Playing the Nationalist Card (Cambridge, 2010), 78-81.

7. Ibid., 2.

8. Liz Fekete, "Neoliberalism and Popular Racism" in Panitch and Albo (see note 1), 1-23; especially 8-9.

9. Gideon Botsch, Christoph Kopke, and Alexander Lorenz, "Wie agiert die 'Alternative für Deutschland' vor Ort? Das Fallbeispiel Brandenburg” in Wut, Verachtung, Abwertung. Rechtspopulismus in Deutschland, ed. Andreas Zick and Beate Küpper (Bonn, 2015), 146166, here 153.

10. Ibid., 14 .

11. Nancy Gibbs, "Chancellor of the Free World," Time online, December 2016; available at http://time.com/time-person-of-the-year-2015-angela-merkel-choice/?iid=toc, accessed 22 October 2016.

12. Foremost among the critical voices is Jürgen Elsässer's in his magazine Compact, see Simpson's article, this issue.

13. "eine starke Selbstvergewisserung der rechtsextremen Szene," Olaf Sundermeyer, "PEGIDA und die Radikalisierung von rechts-Beobachtungen einer menschenfeindlichen Bewegung," in Zick and Küpper (see note 8), 167-177, here 175. 
14. Humayan Ansari and Farid Hafez, "Islamophobia: an introduction," in Ansari and Hafez (see note 2), 7-28, here 11 .

15. Frank Decker, "AfD and Pegida: Understanding Germany's New Populist Right" in Understanding Pegida in Context, ed. Henning Meyer and Ulrich Storck, Friedrich Ebert Stiftung Social Europe Report (March 2015), 15-16, here 15.

16. See Alexander Häusler and Rainer Roeser, "Zwischen Euro-Kritik und rechtem Populismus: Merkmale und Dynamik des Rechtsrucks in der AfD," in Zick and Küpper (see note 8), 124-145. See especially 140 for voting in North-Rhine Westphalia's local spring 2015 elections. For results of right extremist voting patterns in Brandenburg, see Botsch et al. (see note 8), 146-166.

17. Ansari and Hafez (see note 13), 11.

18. For a concise summary of the right populist effects of German globalization fears and Euroscepticism in twenty-first century Germany, see Andreas Klärner, "Externe Faktoren" in Zwischen Militanz and Bürgerlichkeit: Selbstverständnis und Praxis der extremen Rechten (Hamburg, 2008), 291-293.

19. See Ruth Wodak, "Gender and The Body Politic: The Politics of Patriarchy" in The Politics of Fear: What Right-Wing Populist Discourses Mean (London, 2015), especially 150-153. Wodak analyzes the right populist return to traditional gender roles, while paradoxically also empowering some white women to lead. She states: "much fear constructed and launched by the extreme right-wing is projected onto fantasies and imaginaries of both empowered and independent white women as well as women symbolizing the 'Other,' namely the veiled Muslim woman as metonym for the "post-modern stranger,"' 153.

20. Ibid., 60 .

21. Beatrix von Storch, an AfD member of the European Parliament falsely claimed on the Anne Will television program on 24 January 2016: "wir laden immer weitere Menschen $\mathrm{zu}$ uns ein-8-10 Millionen sind auf dem Weg zu uns" (We are inviting more and more people to come here-8-10 million are on their way); available at http://daserste.ndr.de/ annewill/videos/, accessed 25 January 2016.

22. Wodak (see note 18), 60.

23. Richard Fuchs, "Pegida ruft: 'Merkel muß weg'," Deutsche Welle, 12 October 2015; available at http://www.dw.com/de/pegida-ruft-merkel-muss-weg/a-18777509, accessed 25 January 2016.

24. This remark by the AfD's von Storch refers back to Merkel's famous 2015 statement "Wir schaffen das!" (Yes, we can!) in regard to German refugee integration. Angela Merkel, "Sommerpressekonferenz von Bundeskanzlerin Merkel," Die Bundesregierung, 31 August 2015; available at http://www.bundesregierung.de/Content/DE/Mitschrift/ Pressekonferenzen/2015/08/2015-08-31-pk-merkel.html, accessed 25 October 2016. The full context is: "Germany is a strong country. Our guiding motivation as we address these issues has to be: We achieved so much-we can do it! We can do it, and where we face an obstruction, we have to overcome it by working on it. ... Then there is a European dimension, and here I believe that we may say: Europe as a whole must move together. . . . If Europe fails at the refugee problem, its tight connection to universal civil rights will break. It will be destroyed and that Europe will no longer be the one we imagine . . ., the one that we must continue to develop even today as our founding myth." Translation by Helga Druxes.

25. Simone Rafael, "Die Mitte und der 'Genderwahn," in Zick und Küpper (see note 8), 7894, here 94 .

26. epd, "Das Nazi-Phantasma von Dresden,” Tageszeitung, 19 January 2016; available at http://www.taz.de/„Pegida“-Kundgebung-am-Montag/!5269211/, accessed 22 October 2016.

27. Martin Machowetz, "Leipzig: Da eskaliert etwas," Die Zeit, 14 January 2016; available at http://www.zeit.de/2016/03/legida-leipzig-neonazis-ausschreitungen, accessed 22 October 2016. 
28. Ralf Melzer, “'Gewalt entsteht im Kopf'. Interview mit Bundesjustizminister Heiko Maas," in Zick und Küpper (see note 8), 15-20, here 17.

29. Wodak (see note 18), 253.

30. Ibid., 247.

31. "So besonnen relativiert Weise die Flüchtlingskrise," Die Welt, 29 October 2015; available at http://www.welt.de/politik/deutschland/article148175570/So-besonnen-relativiertWeise-die-Fluechtlingskrise.html, accessed 22 October 2016.

32. See Alba and Foner (see note 3), 182-183. See also Arab Center for Research and Policy Studies, "Nowhere Left to Go: Syrian Refugees Head to Europe," September 2015, 5; available at http://english.dohainstitute.org/release/a3b00c1b-17a2-4f6e-aad3caed2ddcedba, accessed 22 October 2016: "This most recent wave of migration has decimated Syria's middle classes: the evidence suggests that those Syrian refugees leaving to Europe today . . . come from the educated professional classes. . . A recent report carried by Swedish broadcaster SVT illustrates this reality: Syrian refugees who arrived in Sweden in 2014 and who were granted indefinite leave to remain had the highest educational attainment of any group of refugees living in the country. Fully 37 percent of them had obtained either university or other tertiary educational qualifications."

33. Dagmar Dehmer, "Kenianischer Schriftsteller angegriffen," Der Tagesspiegel, 1 June 2016; available at http://www.tagesspiegel.de/berlin/berlin-charlottenburg-kenianischer-schriftsteller-angegriffen/13676884.html, accessed 20 June 2016.

34. Ursula Kissel, "Widerwärtige Selbstjustiz oder mutige Zivilcourage?” Deutschlandfunk, 2 June 2016; available at http://www.deutschlandfunk.de/fluechtling-an-baum-gefesseltwiderwaertige-selbstjustiz.1818.de.html?dram:article_id=355990, accessed 20 June 2016.

35. Jörg Diehl, "Gewaltwelle: BKA zählt mehr als tausend Attacken auf Flüchtlingsheime," Spiegel online 28 January 2016; available at http://www.spiegel.de/politik/deutschland/ fluechtlingsheime-bundeskriminalamt-zaehlt-mehr-als-1000-attacken-a-1074448.html, accessed 20 June 2016. See also "Statistik für das erste Halbjahr 2016: 563 Angriffe auf Flüchtlingsheime;" available at http://www.taz.de/!5314713/, accessed 22 October 2016.

36. On "self-credentializing" internet use by Aleksandr Dugin and Kevin MacDonald, see Alexandar Mihailovic, "Hijacking Authority: Academic Neo-Aryanism and Internet Expertise" in Digital Media Strategies of the Far Right in Europe and the United States, ed. Patricia Anne Simpson and Helga Druxes (Lanham, 2015), 83-102, especially 84. There, Mihailovic writes that both "are intent upon the construction of self-validating scholarly subcultures that have a strong diegetic component with specific appeal to non-rationalist modes of discourse, while intersecting with larger communities of political action." These strategies, perhaps given the close association between German and Russian far-right proponents, overlap neatly with those of Pegida, Quer-Denken's Michael Vogt, and Compact's Elsässer.

37. Samuel P. Huntington, “The Clash of Civilizations?” Foreign Affairs 72.3 (1993): 22-49.

38. Wodak (see note 6), 184. 